\title{
Inventory Management System and Performance of Food and Beverages Companies in Nigeria
}

\author{
Lawrence Imeokparia \\ Department of Financial Studies. College of Management Science Redeemer's University Mowe Ogun State \\ Nigeria.
}

\begin{abstract}
Inventory management decisions are an integral aspect of organisations. Inventory postponement as argued by Bucklin (1965) is where a firm deliberately delays the purchase and the physical possession of inventory items until demand or usage requirements are known with certainty. This is an effective supply chain strategy adopted by most manufacturing organisations by reducing the inventory, and in turn reducing the cost of obsolete stock. This study explores the relationship between inventory management and control and performance and Food and Beverages companies in Nigeria. Secondary data were obtained from annual financial reports and accounts of Food and Beverages companies listed on the Nigerian Stock Exchange. The data obtained were analyzed using simple and multiple regression models. The results show that there significant relationship between inventory management and control and the performance of Food and Beverages companies in Nigeria. The multiple regression correlation coefficient $(R)=0.996, R 2=0.990$ and $p$ value $=0 ; 00<0.05$ The results also show the relative importance of the inventory management decisions made by the organisation, and the implications these decisions have on the consumer. The findings show that the three key qualities that are essential in inventory management decisions for manufacturing organisation from the perspective of the third party logistics provider are customer satisfaction, on time delivery and order fulfillment. Key words: inventory, Food organistion, customer, control
\end{abstract}

\section{Introduction}

Inventory Control System is the process of managing inventory in order to meet customer demand at the lowest possible cost and with a minimum of investment, Byoungho (2004). A successfully implemented inventory control program takes into account such things as purchasing goods commensurate with demand, seasonal variation, changing usage patterns, and monitoring for pilferage, Ellram (1996). A preliminary step in the process of inventory control is to determine the approximate costs of carrying inventory. According to Langabeer and Stoughton (2001), these costs include such expenses as storage costs, inventory risks, and the loss-of-opportunity costs associated with tying up capital.

Inventory management is a vital function to help insure the success of manufacturing and distribution companies. The effectiveness of inventory management systems is directly measurable by how successful a company is in providing high levels of customer service, low inventory investment, maximum throughput and low costs, Ellram (1996). The challenge of productive inventory management is to support an upward trend in sales while keeping the investment at the lowest level consistent with adequate customer service. Control of inventory, which typically represents $45 \%$ to $90 \%$ of all expenses for business, is needed to ensure that the business has the right goods on hand to avoid stock-outs, to prevent shrinkage (spoilage/theft), and to provide proper accounting, Khan (2003).

\section{Objectives of the Study}

This project work aims at achieving the following objectives:

1) To describe the relationship between inventory control system and how it affects the success of the company

2) To ascertain the relationship between the financial performance of a company and its inventory control system.

3) To examine the various problems associated with the inventory control system of a company and its decision making process.

\section{Research Questions}

The following research questions are asked to guide the conduct of this study:-

1. To what extent do relationships between inventory postponements affect the success of the organization?

2. Does inventory speculation have any significant relationship with the financial performance of a company?

3. Is there a relationship between inventory control and decision making of the company? 


\section{Hypothesis of the Study \\ Hypothesis One}

Ho: There is no significant relationship between the inventory postponement of the company and its productivity

H1: There is a significant relationship between the inventory postponement and the productivity of the company Hypothesis Two

Ho: There is no significant relationship between the financial performance of a company and its inventory speculations

H1: There is a significant relationship between the financial performance of a company and its inventory speculations

\section{Literature Review}

Graman and Magazine (2006), argued that today, the cost of holding inventory, extensive product proliferation and the risk of obsolescence, especially in rapidly changing markets, make the expense of holding large inventories of finished goods excessive and that high demand items naturally have safety stock assigned to them, but in many organizations there are so many very-low-demand items that keeping any stock of these items is unreasonably expensive, so they argue that companies must now provide good service while maintaining minimal inventories. Therefore, inventory management approaches are essential aspects of any organization.

Wallin et al. (2006), has argued that that a typical manufacturing firm spends on average, 56 cents out of every dollar of revenue to cover the direct cost of purchased goods, and Monczka et al. (2002), and Handfield (2002), have argued that this percentage figure is higher for the typical wholesaler or retailer. Wallin et al. (2006), argued that a firm carrying \$20 million in purchased goods inventory would incur an additional \$6-7 million in material handling and inventory holding costs, but once these direct and indirect costs are reduced, the firm's net profits increase. Therefore, organizations from manufacturing to wholesale to retail require effective inventory management. However, inventory management in the manufacturing organizations needs special attention. Wanke and Zinn (2004,:466) states that inventory management approaches are a "function of product, operational and demand related variables such as delivery time, obsolescence, coefficient of variation of sales and inventory turnover" and that logistics managers are more likely to decentralise inventory in order to stock product close to the customer's facility if the customers demand a reduced delivery time. On the other hand, Imai (1998), states that organizations that have a long lead time of production, in turn leading to a large amount of inventory, means that there is no flexibility to meet changing customer orders on a day-today basis. Therefore, the problem with this inventory management decision is that "when the forecast is off-which is usually the case companies may be left with a volume of unsold products or its market may evaporate overnight when consumer preferences change or when a competitor comes up with a new and better product" (Imai, 1998,:26).

Therefore, for an organisation to adopt the right inventory management approach, this inventory management approach is necessary in order to gain more customers through customer satisfaction, and in order for the third party logistics provider organisation to operate effectively through the preferable approach. Imai (1998) has argued that there is a "push", "pull" and "just in time" inventory management system. The just in time system is based on the "pull" from the market, and this "pull production is based on a short, slim production line with the shortest possible production lead time, which allows the company to respond to the fluctuating orders from the market" (Imai, 1998, p.27). "This system ensures that the minimum-required number of the popular models is always in stock, (and) in addition to increasing flexibility and reducing inventory to the minimum, the number of operators on the line can be drastically reduced, (and so) as a result, the overall cost of operations can be drastically reduced" (Imai, 1998, p.28).

Yang et al (2004) has argued that supply chains have evolved from traditional forecast-driven push to demand-driven pull systems over time, and that postponement is playing an increasingly important role in a supply chain. Yang and Burns (2003) argued that postponement fosters a new way of thinking about the supply chain and Van Hoek (1999), identified that postponement is an important characteristic of modern and competitive supply chains. Chan et al. (2002:1446), states that "Many companies have realized that important cost savings can be achieved by integrating inventory control and transportation policies throughout their supply chains".

Therefore, these companies need to ensure they have an optimal replenishment plan, being an inventory and transportation strategy, in order to minimise total inventory and transportation costs over a finite planning horizon (Chan et al., 2002). These undisclosed companies, as explained by Chan et al. (2002), rely on external third party logistics providers for the transportation of goods from suppliers through warehouses to retailers. "This cost structure, representing quantity discounts, volume-based price incentives, and other forms of economies of scale, has a major impact on the replenishment strategy. It usually reflects either incremental or all-unit discount effects, leading to the following types of cost functions" (Chan et al., 2002:1447). Tarn et al. 
(2003), has described that when a consumer places an order,

"the order goes to the fulfillment operation, the distributor, the manufacturer, or a combination of the above (where) it is then picked, packed, handed to a shipper, and delivered to the customer" (Tarn et al., 2003). The consumer who orders quickly expects delivery also quickly, but when the merchandise is not there, a consumer may not return, a lost sale has just been created and this places increased pressure on managing demand and planning up and down the supply chain (Tarn et al., 2003).

The most common inventory management method is inventory speculation (Wallin et al., 2006). Bucklin (1965), has explained this by stating that a firm would purchase items and physically hold this inventory within its storage facilities before there is a demand from the consumer. There are several advantages to this inventory management method being that there is an ability to respond quickly to demand or requirement as well as the ability to protect itself against fluctuations in prices (Wallin et al., 2006). Rietze (2004) argues that inventory postponement refers to delayed decision-making about a product, and that it is beneficial to delay commitment to product-specific characteristics as late as possible in order to avoid a mismatch between orders and inventory on hand. Bucklin (1965), supported this explanation agreeing that a firm operating under an inventory postponement approach would deliberately delay the purchase and the physical possession of inventory items until demand or usage requirements are known with certainty. Wallin et al. (2006), has elaborated this point by stating that through inventory postponement, a firm can minimise the risk of inventory obsolescence, reduce the opportunity cost of having capital tied up in these items, and avoid acquiring inventory storage and tracking expenses since this inventory is physically located with the supplier. Byoungho (2004), identified five inventory control/ record system. According to him, the ideal inventory and proper merchandise turnover will vary from one market to another. Average industry figures serve as a guide for comparison. Too large an inventory may not be justified because the turnover does not warrant investment, Billington et al (2004). On the other hand, because products are not available to meet demand, too small an inventory may minimize sales and profits as customers go somewhere else to buy what they want where it is immediately available ,Byoungho (2004).

Wanke and Zinn (2004)state that the most profitable policy is not to optimize one of these at the expense of the others.

In a general stores environment the service will normally be taken as 'availability ex stock', whereas in a supply to customer specification, the service expected would be delivery on time against customer requested date, Chan et al (2002). The second target, inventory costs, requires a minimum of cash tied up in stock. This target has to be considered carefully, since there is often the feeling that having any stock in stores for a few months is bad practice. In reality, minimizing the stock usually means attending to the major costs: very low value items are not considered a significant problem. Low inventory can also be considered in terms of space or other critical resources, Van Hoek (1999)..According to Yang et al (2004), the improvement in stock control has been slow and gradual, created by new technology, financial need and competitive pressure. Those companies who can tighten their control faster than the average will flourish, but those which do not keep up with the average, even if they are improving, will gradually dwindle. The trick of the good stock controller is to meet the objectives simultaneously, not one at a time, and of course 'the better the control the smaller the cost, the lower the stock levels, and the better the customer service'. One of the dichotomies of inventory control is that at item level, the more stock the better the availability. However for the whole inventory, experience has shown that the businesses with the highest stock are often those which have the worst availability, Yang et al (2004). These observations are not in conflict if the causes are considered. Stock outs result from holding too little stock of the offending lines, because the forecasts, monitoring or controls are inadequate. High stock levels arise because too much stock has been purchased through bad forecasting, monitoring or controls. High stock and poor availability are caused simultaneously as a result of poor control. The problem rests with the inventory controller and the solution is in improved techniques, Yang et al (2004). Inventory control, according to Ozer, O (2003), is the activity which organizes the availability of items to the customers. goes on to states that conventional supply organization will have many departments including sales, purchasing, finance, quality assurance, contracts and general administration. In some cases there will also be manufacturing, distribution or support services or a variety of industry specific activities. Each of these has a particular view of the role of stock control.

\section{Methodology}

This research work employs the use of secondary data which provides repository records and accounts in a workable format. The instrument used for this research is secondary in nature as quantifiable Inventory data were obtained from the financial reports obtained from the manufacturing companies. The reason for the use of annual reports is because it captures all financial transactions of the companies.

Model Specification 


$$
1 C=\alpha 0+\alpha, R P M+\alpha_{2} W I P+\alpha_{2} F G+\alpha_{4} F S+\alpha_{5} G I T+\alpha_{6} O_{S}
$$

Method of Data Analysis The method used in this study is based largely on deductive method and the use of secondary data collected from various annual financial reports published by Food and Beverages companies listed on the Nigeria Stock Exchanges. The Linear Regression Analysis is divided into two categories:

(i) Simple Linear Regression Model

(ii) Multiple Linear Regression Model

Regression Analysis is a statistical technique for modeling and investigating the relationship between two or more variables. Also many of the forecasting techniques use regression methods for parameter estimations. It is a means of viewing the relationship that exist between two or more variables i.e. one dependent and one or more independent variables.

\section{Data Analysis and Interpretation}

Table 1: Descriptive Statistics

\begin{tabular}{|l|r|r|r|}
\hline & \multicolumn{1}{|c|}{ Mean } & Std. Deviation & $\mathrm{N}$ \\
\hline Inventory Control (IC) & $4.3711 \mathrm{E} 6$ & $1.91796 \mathrm{E} 6$ & 30 \\
Raw \& Packaging Materials & $1.8155 \mathrm{E} 6$ & $8.32840 \mathrm{E} 5$ & 30 \\
(RPM) & & & \\
Work in progress (WP) & 133511.6614 & 73046.32381 & 30 \\
Finished goods (FG) & $1.1969 \mathrm{E} 6$ & $9.34866 \mathrm{E} 5$ & 30 \\
Engineering spares (ES) & 580579.0584 & $1.85016 \mathrm{E} 5$ & 30 \\
Goods in transit (GT) & 156390.8552 & $1.22051 \mathrm{E} 5$ & 30 \\
Other stocks (OS) & $1.9327 \mathrm{E} 6$ & 50503.94475 & 30 \\
\hline
\end{tabular}

Table 1 shows the descriptive statistics of the data collected from financial report of Cadbury Nigeria Plc on Inventory control (IC) and its components for thirty (30) years. The mean IC, in Naira, for the years under reference is 4,371,100; RPM is 1,815,500; WP is 133,511.66; FG is 1,196,900; ES is 580,579.06; GT is $156,390.86$; and OS is $1,932,700$.

Table 2: Pearson Correlation Analysis

\begin{tabular}{|c|c|c|c|c|c|c|c|c|}
\hline & & $\begin{array}{l}\text { Inventory } \\
\text { Control }\end{array}$ & $\begin{array}{c}\text { Raw \& } \\
\text { Packaging } \\
\text { Materials }\end{array}$ & $\begin{array}{l}\text { Work in } \\
\text { progress }\end{array}$ & $\begin{array}{l}\text { Finished } \\
\text { goods }\end{array}$ & $\begin{array}{c}\text { Engineering } \\
\text { spares }\end{array}$ & $\begin{array}{l}\text { Goods } \\
\text { in } \\
\text { transit }\end{array}$ & $\begin{array}{l}\text { Other } \\
\text { stocks }\end{array}$ \\
\hline $\begin{array}{l}\text { Inventory } \\
\text { Control }\end{array}$ & $\begin{array}{l}\text { Pearson } \\
\text { Correlation }\end{array}$ & 1 & $.926^{* * \pi}$ & $.925^{* *}$ & .338 & $.994^{* * *}$ & .286 & $.984^{* 3 *}$ \\
\hline $\begin{array}{l}\text { Raw \& } \\
\text { Packaging } \\
\text { Materials }\end{array}$ & $\begin{array}{l}\text { Pearson } \\
\text { Correlation }\end{array}$ & & 1 & $.808^{* * 2}$ & .344 & $.986^{* * 2}$ & .146 & $.967^{* * 1}$ \\
\hline $\begin{array}{l}\text { Work in } \\
\text { progress }\end{array}$ & $\begin{array}{l}\text { Pearson } \\
\text { Correlation } \\
\end{array}$ & & & 1 & .327 & $.942^{* * *}$ & $.477^{* * *}$ & $.943^{\text {***? }}$ \\
\hline $\begin{array}{l}\text { Finished } \\
\text { goods }\end{array}$ & $\begin{array}{l}\text { Pearson } \\
\text { Correlation } \\
\end{array}$ & & & & 1 & .356 & $.714^{* * *}$ & .273 \\
\hline $\begin{array}{l}\text { Engineering } \\
\text { spares }\end{array}$ & $\begin{array}{l}\text { Pearson } \\
\text { Correlation }\end{array}$ & & & & & 1 & .245 & $1.000^{* *}$ \\
\hline $\begin{array}{l}\text { Goods in } \\
\text { transit }\end{array}$ & $\begin{array}{l}\text { Pearson } \\
\text { Correlation }\end{array}$ & & & & & & 1 & .276 \\
\hline Other stocks & $\begin{array}{l}\text { Pearson } \\
\text { Correlation }\end{array}$ & & & & & & & 1 \\
\hline
\end{tabular}

The correlation results in Table 2 indicated that there is significant direct correlation, at the 0.01 level (2-tailed), between Inventory Control and each of the variables - Inventory Control, Raw \& Packaging Materials, Work in progress, Engineering spares and other stocks. While no significant direct correlation exists, at the 0.01 level (2tailed), between Inventory Control and Finished goods, and Goods in transit. This implies that when raw \& packaging materials, work in progress, engineering spares, other stocks, finished goods and Goods in transit are increasing, the inventory control will be increasing but FG and GT are not significant. 
Further, the multiple correlations $(\mathrm{R})=0.996(99.6 \%)$ is the overall correlation between IC and the variables, which explained that there is a high direct correlation between IC and its components. The adjusted regression coefficient of determination $\left(\mathrm{R}^{2}\right)=0.990(99.0 \%)$ is the amount of information being explained by RPM, WP, ES, OS, FG and GT about IC.

Table 3: ANOVA

\begin{tabular}{|l|r|r|r|r|r|}
\hline Model & Sum of Squares & Df & Mean Square & F & Sig. \\
\hline Regression & $1.059 \mathrm{E} 14$ & 6 & $1.764 \mathrm{E} 13$ & 492.839 & .000 \\
Residual & $8.234 \mathrm{E} 11$ & 23 & $3.580 \mathrm{E} 10$ & & \\
Total & $1.067 \mathrm{E} 14$ & 29 & & & \\
\hline
\end{tabular}

Dependent Variable: Inventory Control

From the ANOVA table, Since the P-value $=0.000<0.05$, the model is adequate. However, the effect of each of the variable on IC is investigated using the regression analysis in the following table.

Table 4: Regression Coefficients

\begin{tabular}{|c|c|c|c|c|c|}
\hline \multirow[t]{2}{*}{ Model } & \multicolumn{2}{|c|}{$\begin{array}{c}\text { Unstandardized } \\
\text { Coefficients }\end{array}$} & \multirow{2}{*}{$\begin{array}{c}\text { Standardized } \\
\text { Coefficients }\end{array}$} & \multirow[b]{2}{*}{$\mathrm{t}$} & \multirow[b]{2}{*}{ Sig. } \\
\hline & B & Std. Error & & & \\
\hline (Constant) & 8389869.819 & 6238968.519 & & 1.345 & .192 \\
\hline $\begin{array}{l}\text { Raw \& Packaging } \\
\text { Materials }\end{array}$ & -1.650 & .291 & -.717 & -5.680 & .000 \\
\hline Work in progress & 2.871 & 2.415 & .109 & 1.189 & .247 \\
\hline Finished goods & .010 & .078 & .005 & .124 & .903 \\
\hline Engineering spares & 18.087 & 1.666 & 1.745 & 10.856 & .000 \\
\hline Goods in transit & -.442 & .708 & -.028 & -.623 & .539 \\
\hline Other stocks & -6.131 & 3.404 & -.161 & -1.801 & .085 \\
\hline
\end{tabular}

Dependent Variable: Inventory Control

In Table 4, the P-values of each of the independent variables suggest that only RPM and ES have significant effect on IC, since P-value $0.000<0.05$, respectively. Hence, this further suggests that major part of inventory control is determined by Raw \& Packaging Materials and Engineering spares. And based on the standardized coefficient, engineering parts (ES) has the strongest direct effect on inventory control (IC), while RPM has a significant indirect effect on IC.

Model Specification

$\mathrm{IC}=8389869.819-1.650 \mathrm{RPM}+2.871 \mathrm{WP}+0.010 \mathrm{FG}+18.087 \mathrm{ES}-0.442 \mathrm{GT}-6.131 \mathrm{OS}$

\section{Conclusion}

It has been shown that inventory management approaches from manufacturing organizations can be improved. Their highest ranking requirement is customer satisfaction, and through an example of inventory postponement, there are situations where inventory is not available and part delivery is delayed and orders cannot be fulfilled on time. In order to meet these requirements, the high manufacturing organization needs to have more accurate forecasting, and to strengthen its communication with its customers.

In order for the manufacturing industry to work out how to incorporate inventory postponement and inventory speculation to incorporate consumer demand and to align this consumer demand with the organization's supply chain, the forecasting and planning processes needs to be improved (Langabeer \& Stoughton, 2001). This "can be achieved, and the supply chain performance metrics (and overall firm performance) will be maximized if the demand forecasting processes are collaborative, sophisticated, oriented towards the product life cycle, and developed using non-constrained consumer demand data.

The implication of inventory management approaches is that through inventory postponement, customers are frequently waiting for stock to fulfill their requirements, and in turn puts added pressure on to the third party logistics provider who faces these inventory management issues directly with the customers. The implications of this can be negative feedback and negative customer relationships, as opposed to positive customer relationships if the inventory management approach adopted a level of inventory speculation, where forecasting would increase the inventory and would be more likely be available to fulfill the customer's requirements. 


\section{References}

[1]. Andel, Tom, and Daniel A. Kind. "Flow It, Don't Stow It." Transportation and Distribution May 1996.

[2]. Bergin, Sarah. "Make Your Warehouse Deliver: New Developments in Warehouse Management Systems Inspire New Productivity in Needy Operations." Transportation and Distribution. February 1997.

[3]. Billington, C., Callioni, G., Crane, B., Ruark, J.D. (2004) “Accelerating the Profitability of Hewlett-Packard's Supply Chains". Interfaces. Linthicum: Jan/Feb 2004.

[4]. Breugelmans, E., Campob, K., Gijsbrechts (2006), “Opportunities for active stock-out management inonline stores: The impact of the stock-out policy on online stock-out reactions 2006 NewYork University. Published by Elsevier Inc.

[5]. Bucklin, L.P. (1965), "Postponement, speculation, and the structure of distribution channels", Journalof Marketing Research, Vol. 2 No. 1, pp. 26-32 Byoungho, J., (2004) "Achieving an Optimal Global Versus Domestic Sourcing Balance under Demand Uncertainty". International. Journal of Operations and Production Management.Bradford. Vol.24, Iss 11/12, p.1292

[6]. Chan, L.M.A., Muriel, A., Shen, Z-J.M., Simchi-Levi, D. and Teo C-P.(2002) "Effectivezeroinventory-ordering policies for the single-warehouse multiretailer problem with piecewise linear cost structures".Management Science. Linthicum: Vol.48, Iss. 11; pg.

[7]. $1446,15 \mathrm{pgs}$

[8]. Eisenhardt, Kathleen M. (1989), "Building Theories from Case Study Research,” Academy of Management Review. Vol. 14, No. 4, pp. 532-550.

[9]. Ellram, Lisa M. (1996), "The Use of the Case Study Method in Logistics Research,” Journal of Business Logistics. Vol. 17, No. 2, pp. 93-139.

[10]. Fleischmann, M., van Nunen, J.A.E.E., and Grave, B., (2003) "Integrating Closed-Loop Supply Chains and Spare-Parts Management at IBM" Interfaces. Linthicum: Vol.33, Iss. 6; pg. 44

[11]. Graman, G.A. and Magazine, M.J., (2006) "Implementation issues influencing the decision to adopt postponement" International Journal of Operations \& Production Management;Volume: 26 Issue: 10; pg.

[12]. Handfield, R.B. (2002), "Reducing costs across the supply chain", Optimize, Dec., pp. 54-60.

[13]. Imai, M., "Will America's corporate theme song be "Just in Time"?" (1998). The Journal for Qualityand Participation. Cincinnati: Vol.21, Iss. 2; pg. 26, 3 pgs

[14]. Kapuscinski, R., Zhang, R.Q., Carbonneau, P., Moore, R., and Reeves, B., (2004) "Inventory Decisions in Dell's Supply Chain" Interfaces. Linthicum:Vol.34, Iss. 3; pg. 191, 15 pgs

[15]. Khan S., (2003) "Supplier choice criteria of executing agencies in developing countries."The International Journal of Public Sector Management; 16, 4/5; ABI/INFORM Global, pg. 261

[16]. Kuo, C-H, Dunn, K.D. and Randhawa, S.U. "A case study assessment of performance measurement in distribution centers." Industrial Management + Data Systems. Wembley:1999. Vol. 99, Iss.2; p. 54

[17]. Langabeer, J., Stoughton, T., (2001) "Demand planning and forecasting in the high technology industry. The Journal of Business Forecasting Methods \& Systems. Flushing: Vol.20, Iss. 1; pg. 7, 4 pgs

[18]. Monczka, R.M, Trent, RJ. andHandfield, R.B. (2002), Purchasing and Supply Chain Management,2nd éd., South-Western, Cincinnati, OH.National Science Foundation Science Engineering Indicators -1998N

[19]. Ozer, O., (2003) "Replenishment strategies for distribution systems under advance demand information" Management Science. Linthicum.Vol.49, Iss. 3; pg. 255, 18 Pagh, J.D. and Cooper, M.C. (1998), "Supply chain postponement and speculation strategies:

[20]. how to choose the right strategy", Journal of Business Logistics, Vol. 19 No. 2, pp. 13-33.

[21]. Patton, M.Q. (1990), 2nd edition, Qualitative Evaluation and Research Methods, New Bury Park, CA.

[22]. Rossman, G.B. and Wilson, B.L. (1985), "Numbers and words: combining quantitative and qualitative methods in a single largescale evaluation study", Evaluation Review, Vol. 9 No. 5.

[23]. Svensson, G., (2003), "The bullwhip effect in intra-organisational echelons"International Journal of Physical Distribution \& Logistics Management. Bradford:2003.Vol.33, Iss. 1/2; pg. 103, 29 pgs

[24]. Tarn, J.M., Razi, M.A., Wen, H.J., Perez Jr, A.A. (2003) "E-fulfillment: the strategy and operational requirements". Bradford: .Vol.16, Iss. 5; pg. 350, 13 pgs Van Hoek, R.I. (1999), "Postponement and the reconfiguration challenge for food supply chains", Supply Chain Management, Vol. 4 No.1, pp.18-34.

[25]. Van Hoek, R.I. (2000), "Role of third party logistic services in customization through postponement" International Journal of Service Industry Management; Volume: 11 Issue:4; Wallin, C., Rungtusanatham, M.J., and Rabinovich, E., (2006) "What is the "right" inventory management approach for a purchased item?" International Journal of Operations \&Production Management. Bradford: Vol. 26, Iss. 1/2; pg. 50, 19 pgs

[26]. Wallin, C., Rungtusanatham, M., Rabinovich, E., Hwang, Y., (2007) Inventory Ownership and Placement Decisions for an Externally $\quad$ Sourced Item within a B $\quad$ B (http://marriottschool.byu.edu/emp/BMS/Documents/Cindy\%20Wallin\%20Paper.pdf) (accessed 20.5.11, 5.7.07)

[27]. Wanke, P. F., and Zinn, W., (2004) "Strategic Logistics Decision Making".International Journal of Physical Distribution and Logistics Management. 34, 6; ABI/INFORM Global, pg 466

[28]. Xu, K., Windle, RJ., Grimm, C.M. and Corsi, T.M. (1994), "Re-evaluating returns to scale in transport", Journal of Transport Economics and Policy, Vol. 28 No. 3, pp. 275-86.

[29]. Yang, B.,Burns, N.D., Backhouse, C.J.(2004). "Postponement: a review and an integrated". Internet J. of Operations \& Production Management 24(5) pp. 468-487

[30]. Yang, B., Burns, N.D. (2003), "Implications of postponement for the supply chain", International Journal of Production Research, Vol. 41 No.9, pp.2075-90

[31]. Yin, R.K., (2003). Case Study Research Design and Methods. Third Edition.Sage Publications. California.

Inventory control of cadbury nigeria plc from 1982 to 2011

\begin{tabular}{|r|r|r|r|r|r|r|r|}
\hline \multicolumn{1}{l|}{ Year } & IC & RPM & WIP & FG & ES & GIT & OS \\
\hline 1982 & 210465.29 & 8870.02 & 50222.29 & 2529534.87 & 172411.23 & 328212.53 & 1820311.48 \\
\hline 1983 & 5127696.02 & 2144089.10 & 160677.79 & 1123337.50 & 659062.22 & 147709.57 & 1954955.24 \\
\hline 1984 & 3542960.61 & 1455946.23 & 92708.47 & 53917.86 & 502223.32 & 5671.60 & 1911561.97 \\
\hline 1985 & 6229448.64 & 2622505.38 & 207931.97 & 1941798.52 & 768101.03 & 254344.47 & 1985123.46 \\
\hline
\end{tabular}


Inventory Management System And Performance Of Food And Bravages Companies In Nigeria

\begin{tabular}{|c|c|c|c|c|c|c|c|}
\hline 1986 & 5212134.16 & 2180754.85 & 164299.34 & 1186064.21 & 667418.93 & 155882.05 & 1957267.33 \\
\hline 1987 & 4802456.69 & 2002859.77 & 146728.27 & 881726.35 & 626873.76 & 116230.76 & 1946049.53 \\
\hline 1988 & 4286396.91 & 1778770.08 & 124594.46 & 498360.06 & 575800.10 & 66283.08 & 1931918.76 \\
\hline 1989 & 6825143.24 & 2881175.05 & 233481.32 & 2384323.28 & 827056.03 & 311999.73 & 2001434.79 \\
\hline 1990 & 6311289.29 & 2658043.21 & 211442.12 & 2002595.64 & 776200.67 & 262265.55 & 1987364.42 \\
\hline 1991 & 5905933.93 & 2482024.93 & 194056.42 & 1701468.54 & 736083.26 & 223032.58 & 1976264.97 \\
\hline 1992 & 3431316.60 & 1407466.82 & 87920.06 & 136855.05 & 491174.08 & -16477.24 & 1908504.93 \\
\hline 1993 & 6541992.13 & 2758221.77 & 221336.96 & 2173978.29 & 799032.99 & 284594.50 & 1993681.54 \\
\hline 1994 & 5737561.71 & 2408912.32 & 186834.93 & 1576389.55 & 719419.71 & 206736.40 & 1971654.60 \\
\hline 1995 & 4932846.77 & 2059479.32 & 152320.70 & 978589.47 & 639778.28 & 128850.77 & 1949619.87 \\
\hline 1996 & 4088028.16 & 1692632.02 & 116086.42 & 350997.49 & 556167.84 & 47083.64 & 1926487.02 \\
\hline 1997 & 1527446.53 & 580745.46 & 6263.05 & 1551186.56 & 302750.90 & 200746.38 & 1856373.10 \\
\hline 1998 & 2822495.88 & 1143097.37 & 61807.73 & 589130.83 & 430920.00 & 75402.94 & 1891834.18 \\
\hline 1999 & 4345023.62 & 1804227.68 & 127108.96 & 541912.19 & 581602.30 & 71957.36 & 1933524.08 \\
\hline 2000 & 3261428.75 & 1333696.08 & 80633.57 & 263059.95 & 474360.53 & 32920.11 & 1903853.05 \\
\hline 2001 & 3381197.10 & 1385703.33 & 85770.43 & 174087.41 & 486213.82 & 21328.14 & 1907132.55 \\
\hline 2002 & 8393716.01 & 3562299.59 & 300757.42 & 3549571.86 & 982295.34 & 463816.57 & 2044385.49 \\
\hline 2003 & 4669481.43 & 1945117.65 & 141024.96 & 782942.77 & 613713.40 & 103360.53 & 1942408.39 \\
\hline 2004 & 3058204.00 & 1245449.38 & 71917.25 & 414029.90 & 454247.68 & 52589.55 & 1898288.35 \\
\hline 2005 & 864853.34 & 293026.27 & 22155.58 & 2043408.40 & 237175.04 & 264876.52 & 1838229.96 \\
\hline 2006 & 1220371.96 & 447403.85 & 6907.38 & 1779303.62 & 272360.19 & 230467.08 & 1847964.78 \\
\hline 2007 & 3587784.00 & 2481360.00 & 115208.00 & 374108.00 & 610629.00 & 6479.00 & - \\
\hline 2008 & 3073242.00 & 1932220.00 & 73319.00 & 516796.00 & 495099.00 & 55808.00 & - \\
\hline 2009 & 6879018.00 & 2940093.00 & 125332.00 & 2990221.00 & 798043.00 & 25329.00 & - \\
\hline 2010 & 5367437.00 & 1383210.00 & 234748.00 & 419778.00 & - & 162916.00 & 1978095.00 \\
\hline 2011 & 5494652.00 & 1446701.00 & 201755.00 & 397337.00 & - & 368354.00 & 1918274.00 \\
\hline
\end{tabular}

Source: Financial Report of Cadbury Nigeria Plc 